\title{
Analysis of Options to Reduce Noise Exposure to Shooters on Sport Shooting Ranges
}

doi:10.2478/mape-2021-0030

Date of submission to the Editor: 06/2021

Date of acceptance by the Editor: 08/2021

MAPE 2021, volume 4, issue 1, pp. 330-342

\author{
Arkadiusz Boczkowski \\ ORCID ID: 0000-0002-5042-5862 \\ Silesian University of Technology, Poland \\ Mateusz Adamski \\ Silesian University of Technology, Poland \\ Jacek Bień \\ Silesian University of Technology, Poland \\ Karol Chwalny \\ Silesian University of Technology, Poland \\ Michał Nosek \\ Silesian University of Technology, Poland \\ Patryk Paszek \\ Silesian University of Technology, Poland \\ Marzena Pisarska \\ Silesian University of Technology, Poland
}

\section{INTRODUCTION}

Shooting sports are currently experiencing a renaissance. Shooting is currently enjoying a very high and growing interest. More and more people are taking up sport and recreational shooting, which is facilitated by the law regulating access to firearms in Poland and by the increasing number of publicly accessible shooting ranges. Target shooting, dynamic shooting and dart shooting (trap, skeet, sporting, compak sporting) are developing intensively. Shooting, like any other sport, requires constant and intensive training. It involves dozens and sometimes hundreds of shots a day. Prolonged exposure to a shooting range with very high intensity impulsive noises causes considerable discomfort, which may even lead to temporary or permanent hearing damage. In extreme conditions, permanent hearing damage can also occur from a single exposure to a sound pulse with a significant sound pressure level. In addition, impulsive noises can cause headaches, increased nervousness, reduced stress tolerance, drowsiness or the emergence of a habit of talking loudly in shooters. All of this makes it necessary to counteract the existing risk of shooters being exposed to very high levels of noise through the use of various noise protection measures. The aim of this study is to assess the noise exposure of shooters using sport shooting ranges and to analyse the possibilities of reducing the exposure by using hearing protectors and acoustic silencers. The article was 
written as part of the PBL project carried out by a group of students at the Silesian University of Technology under the direction of Eng. Dr Arkadiusz Boczkowski.

\section{ASSESSMENT OF NOISE EXPOSURE OF SHOOTERS}

The weapon, when fired, emits an impulse noise characterized by a rapid increase in sound pressure over a duration of less than 1 s (Młyński, 2013). In assessing a shooter's exposure to noise, the risk should be assessed as a function of the conditions on the range, the means employed in the particular circumstances, taking into account the level and type of exposure (Konopka et al., 2002). We can distinguish between two methods of noise measurement and assessment: the direct and the indirect method.

The direct method consists of measuring the sound level A over the entire exposure time and reading the readings determined by a measuring instrument (so-called noise dosimeter). The results obtained reflect the shooter's actual exposure to noise during the specified exposure time. In the case of impulsive noise, this method is difficult to apply due to the need for specialised microphones with very high dynamics, very short signal integration times (less than $2 \mathrm{~ms}$ ) and the ability to measure sound levels of approximately 170-180 $\mathrm{dB}(\mathrm{A})$. The designs of typical dosimeters are designed to measure typical industrial noise levels and do not provide correct measurements for impulsive noise with very high instantaneous levels.

The indirect method consists in measuring the noise in a much shorter time than the actual exposure time and calculating the noise dose based on the dependence (1) and (2):

- 8-hour noise exp. 8-hour noise exposure level osure level $L_{E X, 8 h}$

$$
L_{E X, 8 h}=L_{A e q, T e}+10 \log \frac{T_{e}}{T_{0}}, d B
$$

where:

$L_{A e q, T e}$ - noise level operating at time $T_{e}$,

$T_{0}$ - a reference time of 8 hours (28800 seconds),

- daily noise exposure $E_{A, 8 h}$

$$
E_{A, 8 h}=1,15 \cdot 10^{-5} * 10^{0,1 \cdot L_{E X, 8 h}}, P a^{2} S
$$

where:

$L_{E X, 8 h}-8$-hour noise exposure level.

The assessment of noise exposure involves comparing measured or determined noise values with the limit values set out in the Regulation of the Minister of Family, Labour and Social Policy of 12 June 2018 on the maximum permissible concentrations and intensities of factors harmful to health in the working environment (Journal of Laws 2018, item 1286, 2018). The permissible values of the assessed noise level indicators are presented in Table 1. None of the given values shall be exceeded. The last two values are used to assess shortterm and impulsive noise. 
Table 1 Summary of permissible noise indicators at workplaces

\begin{tabular}{|c|c|}
\hline Noise characterisation values & Permissible value \\
\hline $\begin{array}{c}\text { Noise exposure level related to } \\
\text { an eight-hour working day } L_{E X, 8 h}[d B]\end{array}$ & 85 \\
\hline Daily exposure $E_{A, 8 h}\left[\mathrm{~Pa}^{2} \cdot s\right]$ & 3640 \\
\hline Weekly exposure $E_{A, w}\left[\mathrm{~Pa}^{2} \cdot s\right]$ & 18200 \\
\hline Maximum sound level $A, L_{A m a x}[d B]$ & 115 \\
\hline Peak sound level $C, L_{\text {peak }}[d B]$ & 135 \\
\hline
\end{tabular}

Source: own study based on the Regulation, 2018

The assessment of the risk related to exposure to noise is carried out on the basis of the multiplicity $\mathrm{K}$ of the exceedance of the NDN value (PawlaczykŁuszczyńska, 2010). When $\mathrm{K} \leq 0.5$, the risk is low (negligible), when $\mathrm{K} \leq 1$, the risk is medium (acceptable) and when $K>1$ the risk is assessed as high and therefore unacceptable. If the indicators described are exceeded, corrective or preventive action must be taken.

\section{REVIEWING THE POSSIBILITIES OF REDUCING THE EXPOSURE OF SHOOTERS TO NOISE Introduction}

The noise generated by gunshots is characterized by very high energy which affects not only the shooter himself, but also the surroundings, including other people in the area of shooting positions (instructors, other shooters, etc.). So there is a need to reduce exposure to above-normal, annoying and harmful noise.

The most common and compulsory method of hearing protection used on shooting ranges today is individual hearing protectors in the form of headphones or earplugs. In some cases, properly shielded and sound-absorbing lined shooting positions are also used to protect those in the vicinity of the shooter from excessive noise. Currently, methods limiting the acoustic energy generated during the shot itself are also increasingly used. One of them is the use of subsonic ammunition, thanks to which the bullet does not exceed the speed of sound in any phase of its flight, which makes the shot itself much quieter. A second method is to use silencers at the end of the barrel. The latter, according to Polish legislation, are not yet allowed for use on sport shooting ranges, but their use gives very good and noticeable results in noise suppression. However, silencers are authorised for the sanitary and reduction hunting of feral pigs in connection with preventing the spread of African swine fever (ASF). 


\section{Use of hearing protectors}

Hearing protectors are the simplest and fastest way to protect the hearing organ against the effects of excessive noise (Kozłowski, 2012). Depending on the design solution, we can talk about ear muffs or earplugs. Choosing the right hearing protectors should take into account, first of all, the requirements regarding the minimum sound attenuation, noise structure (spectrum), comfort of use and the working environment. Examples of hearing protectors of the type of ear muffs are shown in Fig. 1, and their attenuation capacity is summarized in Table 2.
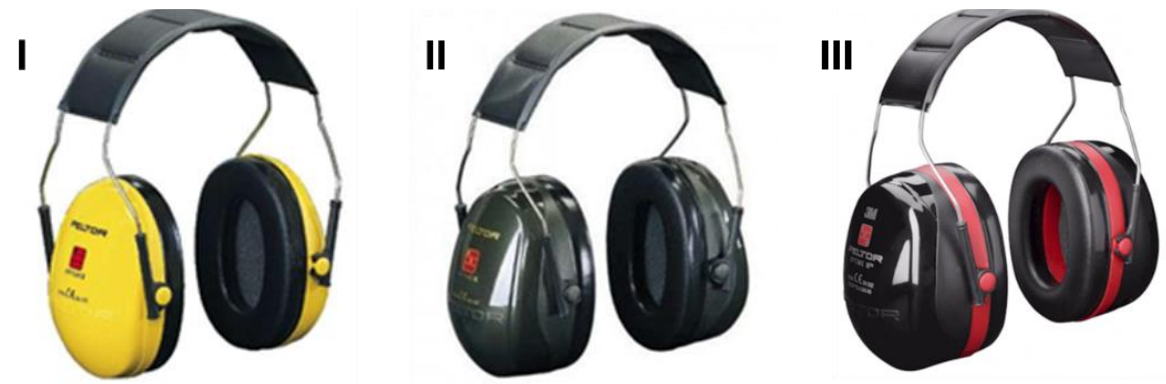

Fig. 1 Peltor Optime I, II and III hearing protectors

Table 2 Noise suppression of Peltor Optime ear muffs

\begin{tabular}{|c|c|c|c|c|c|c|c|c|}
\hline \multirow{2}{*}{$\begin{array}{c}\text { Type } \\
\text { of protector }\end{array}$} & \multirow{2}{*}{$\begin{array}{l}\text { SNR, } \\
\text { dB }\end{array}$} & \multicolumn{7}{|c|}{$\begin{array}{l}\text { Attenuation in the frequency } \\
\text { band in } \mathrm{Hz}\end{array}$} \\
\hline & & 125 & 250 & 500 & $1 \mathrm{k}$ & $2 k$ & $4 k$ & $8 k$ \\
\hline Peltor Optime I & 26 & $\begin{array}{l}\stackrel{3}{+} \\
\underset{+}{+} \\
\stackrel{1}{\sim}\end{array}$ & $\begin{array}{l}0 \\
\stackrel{9}{ } \\
\stackrel{+}{\sigma}\end{array}$ & 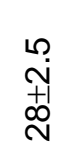 & 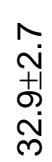 & $\begin{array}{l}\dot{\nabla} \\
\dot{m} \\
+1 \\
\dot{\omega} \\
\ddot{m}\end{array}$ & $\begin{array}{l}\circ \\
\dot{m} \\
+1 \\
\dot{\infty} \\
\dot{m}\end{array}$ & $\begin{array}{l}\infty \\
\text { m. } \\
+1 \\
\infty \\
\dot{\infty}\end{array}$ \\
\hline Peltor Optime II & 31 & $\begin{array}{l}0 \\
\stackrel{0}{+1} \\
\stackrel{0}{D}\end{array}$ & $\begin{array}{l}\stackrel{0}{0} \\
\stackrel{i}{+} \\
\stackrel{N}{N}\end{array}$ & 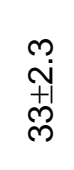 & 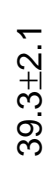 & 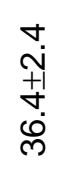 & $\begin{array}{l}\circ \\
\dot{+} \\
+1 \\
\dot{+} \\
\dot{D}\end{array}$ & $\begin{array}{l}\text { m } \\
\text { N } \\
\stackrel{+}{ } \\
\stackrel{+}{+}\end{array}$ \\
\hline Peltor Optime III & 35 & $\begin{array}{l}\bar{i} \\
\stackrel{+}{N} \\
\stackrel{-}{n}\end{array}$ & $\begin{array}{l}0 \\
\stackrel{\sim}{1} \\
\text { 莴 } \\
\sim\end{array}$ & 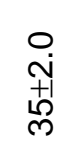 & $\frac{\bar{N}}{\frac{\bar{y}}{\dot{y}}}$ & 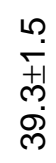 & 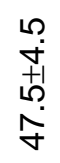 & 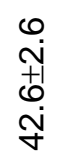 \\
\hline
\end{tabular}

Source: own study based on the 3M catalog

\section{Silencing of shooting positions}

The shooting positions are built in such a way as to minimize the risk of an uncontrolled shot being fired in a direction other than the intended one. Thus, the shooter is usually separated from the surroundings by partitions that allow him to fire only in the direction of the bullet trap. Appropriate shaping of these partitions (usually wooden) and their lining with a material with sound absorbing properties (e.g. hydrophobic rock wool covered with a fleece) will significantly reduce the energy of the reflected wave. For external surface finishes, hard materials that are not capable of absorbing sounds, e.g. plexiglass boards, 
drywall, concrete, etc. should not be used. A good solution is also the use of spatial sound absorbers, which reduce the reverberation time - especially in the case of indoor shooting ranges. The topic of designing shooting positions and silencing shooting ranges is an area of separate considerations.

\section{Application of subsonic ammunition}

Subsonic ammunition is ammunition with a projectile speed not exceeding the speed of sound, i.e. approx. $344 \mathrm{~m} / \mathrm{s}$ at $20^{\circ} \mathrm{C}$. This prevents a supersonic shock wave from occurring during the projectile's flight, resulting in a so-called supersonic thunder. Such ammunition is usually quieter and this is clearly perceptible by shooters. Subsonic ammunition bullets tend to be heavier, which consequently maintains a correspondingly high projectile energy. The use of subsonic ammunition is limited to selected calibres - usually pistols. More and more often it is used in shooting ranges, thanks to which we can effectively reduce the level of noise emitted during the shot by few to several $\mathrm{dB}$. When combined with an additional silencer installed on the barrel, these effects can be much greater. In the case of rifle bullets, the use of subsonic ammunition is associated with a significant decrease in the initial energy of the bullet and a loss of effective firing range. This does not mean that such ammunition is not produced, but it has special applications.

\section{Acoustic silencers}

Acoustic silencers are usually cylindrical in shape and are usually threaded at the end of the barrel. The task of the acoustic silencer is to limit the energy of the acoustic wave generated during the shot using typical physical phenomena such as: reflection, interference, wave compensation or absorption. Details of the construction of acoustic silencers for weapons can be found in the literature (Rusiecki, 2013). A weapon equipped with an acoustic silencer must, of course, be properly shot, because the silencer changes the weight of the barrel, and thus also changes the natural frequencies of this system. A significant advantage of acoustic silencers is a significant reduction in the noise generated during shooting, a change in the frequency of the sound spectrum to a more acceptable one (reduction of low frequencies), as well as a significant reduction in the recoil of the weapon, which is especially important for people who feel fear of the so-called 'kick of the gun'. The silencer does not have a negative effect on reducing the energy of the shot, and interestingly, in some cases, even an increase in energy by a few joules was observed. This is due to the extension of the barrel by the length of the silencer, and thus a slight increase in the velocity of the projectile at the outlet of the barrel. The effectiveness of noise suppression with noise silencers is discussed in detail later in the article. An example of the A-TEC model H2 acoustic silencer is shown in Fig. 2.

In the current legal situation, firearms equipped with a noise silencer are classified as particularly dangerous and are not allowed for general use. The use of noise silencers is possible in the case of sanitary shots of animals. 


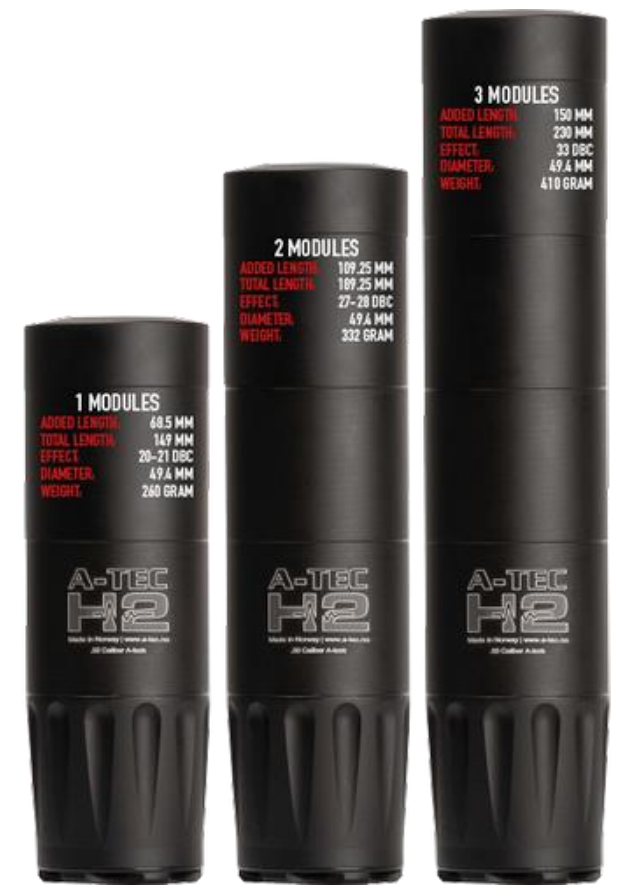

Fig. 2 Examples of A-TEC silencers, model H2

This is regulated by the Act of 20 December 2019 on combating infectious diseases in animals (Journal of Laws 2020, item 148). Therefore, at present, only members of the Polish Hunting Association who perform sanitary shooting of wild boars can use such weapons. Of course, they can also use this weapon in a shooting range - for the purpose of shooting it or training it. In other cases, the use of a weapon equipped with a silencer may be classified as the use of a particularly dangerous weapon which is against the law.

From the point of view of the shooter's hearing protection and the need to reduce the noise emitted from the shooting range to the external environment (Boczkowski, 2020) a change in the law in this respect is necessary, and the approval of noise silencers for use in sport shooting and hunting should take place as soon as possible.

\section{ANALYSIS OF THE EFFECTIVENESS OF REDUCING THE NOISE OF A WEAPON SHOT WITH THE APPLICATION OF SUBSONIC AMMUNITION AND A SILENCER \\ Description of the experiment and measuring station}

In order to analyse the possibilities of noise reduction during shooting, it was decided to analyse the use of acoustic silencers and subsonic ammunition. The acoustic tests were carried out at the HUBERTECH shooting range in Jaworzno on December 15, 2020. On that day, there was no wind, the air temperature was around 1-4 degrees Celsius, the atmospheric pressure was $1024 \mathrm{hPa}$, and the relative humidity was around $88 \%$. Measurements were carried out in free-field acoustic conditions, i.e. in an open area with negligible influence of reflections from cubature objects. The noise tests were carried out at the shooter's ear, 
during target shooting with the Glock 45 pistol (Fig. 3a) in the 9-19 mm calibre, with the use of the following ammunition:

- $\quad$ standard Sellier \& Bellot Luger FMJ weighing 8.0 grams (124 grains), initial speed $\mathrm{v}=360 \mathrm{~m} / \mathrm{s}$ and initial energy $\mathrm{E} 0=518 \mathrm{~J}$,

- Subsonic Sellier \& Bellot Luger FMJ Subsonic weighing 9.7 grams (150 grains), initial velocity $v=305 \mathrm{~m} / \mathrm{s}$ and initial energy $E 0=451 \mathrm{~J}$.

Shooting with any type of ammunition was carried out without an acoustic silencer and with a silencer. A-Tec PMM-6 M13.5 $\times 1$ LH silencer was used. For this silencer, the manufacturer states the effectiveness at the level of $36 \mathrm{~dB}$ (C) when shooting with a wet silencer, but also notes that when shooting with a dry silencer, its effectiveness is lower by approx. 7-8 dB (C). Thus, an attenuation efficiency of $28 \mathrm{~dB}(\mathrm{C})$ can be expected.

a)

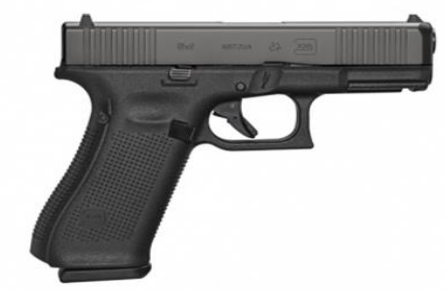

b)

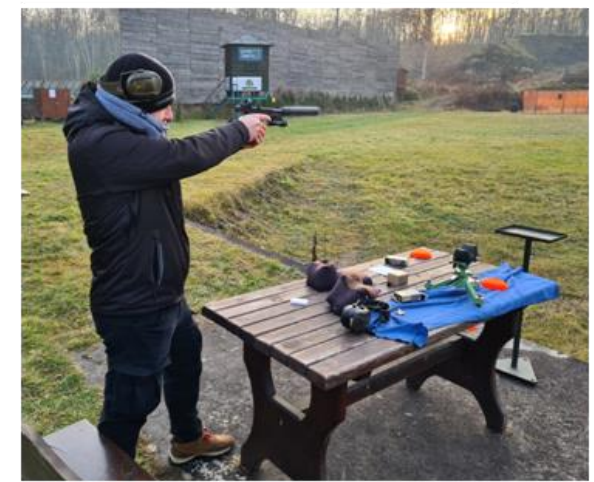

c)

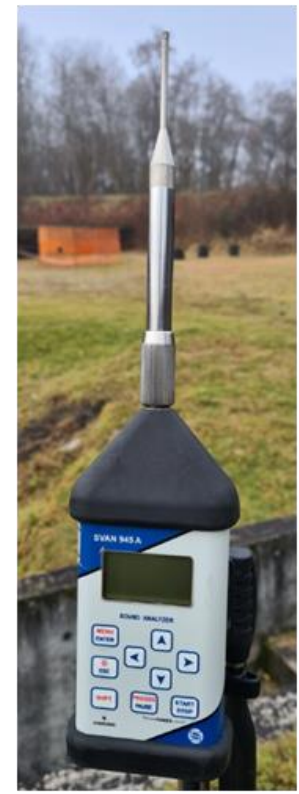

Fig. 3 Basic elements of the measuring station:

a) Glock 45 pistol, b) firing point, c) measuring instrument

To ensure a sufficiently wide and at the same time high frequency response of the measuring equipment, a measuring set consisting of a measuring microphone with a diameter of $1 / 8$ inch by Brüel \& Kjær type 4138 with a sensitivity of $1 \mathrm{mV} / \mathrm{Pa}$, frequency range from 6.5 to $140 \mathrm{kHz}$, dynamic range from 52,2 to $168 \mathrm{~dB}$ and a polarization voltage of $200 \mathrm{~V}$ was used. The used UA-0036 adapter allowed for the connection of the microphone to the Svantek SVAN 945A meter. Projectile speed and energy were measured at a distance of $1 \mathrm{~m}$ from the barrel using an LMBR R2A chronometer with a measuring range of up to $2000 \mathrm{~m} / \mathrm{s}$ and a measurement error of less than $1 \%$ at $1000 \mathrm{~m} / \mathrm{s}$.

\section{Noise measurement results during shooting and their analysis}

During the field sound measurements, the course of changes in the instantaneous acoustic pressure was recorded with a time resolution of $2 \mathrm{~ms}$ (0.002 s). The following sound levels were recorded in real time: LA, LAmax, LAmin, 
Lc, Lcpeak with changes in their frequency spectra in octave and third octave bands. The recorded acoustic waveforms were the basis for processing the results using the SvanPC software and determining the appropriate indicators describing the recorded sound. An exemplary course of changes in the instantaneous A-sound level at the shooter's ear during a shot without a silencer and with a silencer is shown in Fig. 4.
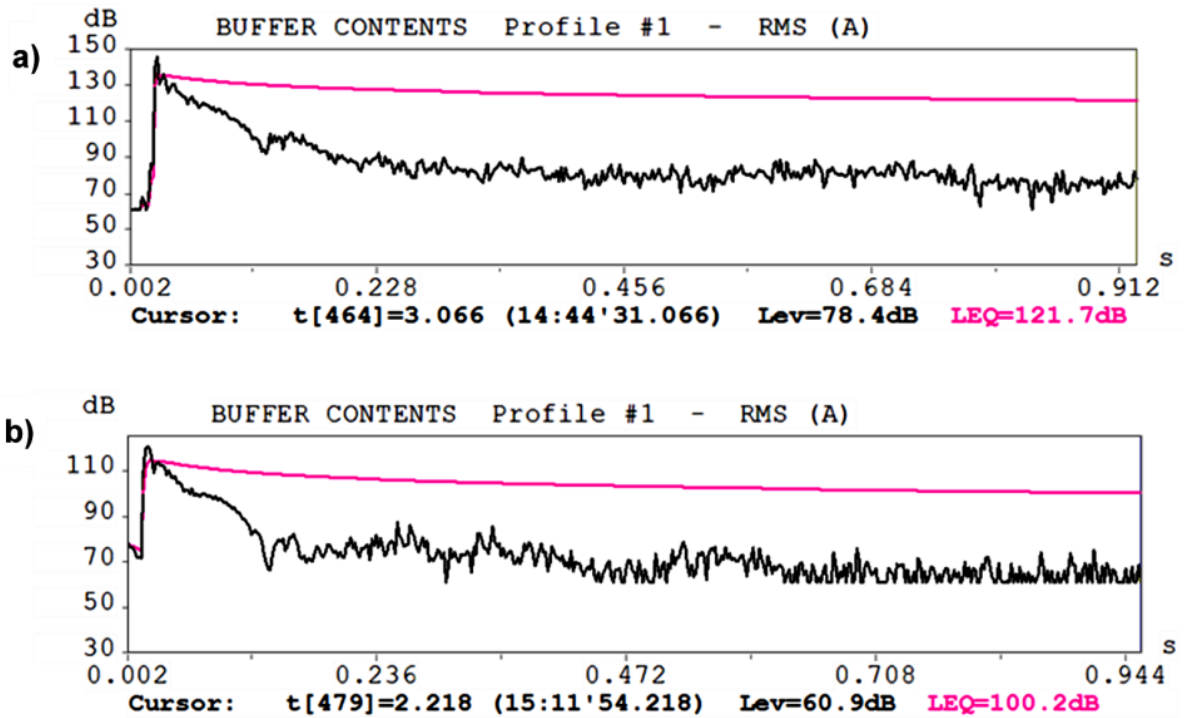

Fig. 4 The course of the instantaneous and average A-sound level at the shooter's ear: a) shot without a silencer, b) shot with a silencer

A summary of the results of measurements and acoustic calculations of the sound level at the shooter's ear during shooting with normal and subsonic ammunition, as well as with the use of an acoustic silencer, is given in Table 3.

Table 3 Results of measurements and calculations of selected sound level indicators during shooting

\begin{tabular}{|c|c|c|c|c|c|c|c|}
\hline \multirow{2}{*}{ Lp. } & \multicolumn{5}{|c|}{ Sound level, dB } & \multirow{2}{*}{$\begin{array}{l}\text { Speed } \\
\text { Vo, } \mathrm{m} / \mathrm{s}\end{array}$} & \multirow{2}{*}{$\begin{array}{c}\text { Energy } \\
E_{0}, J\end{array}$} \\
\hline & $\mathrm{L}_{\text {Aeq, 1s }}$ & $\mathrm{L}_{\text {Amax }}$ & $\mathrm{L}_{\text {Ceq,1s }}$ & $\mathrm{L}_{\mathrm{Cmax}}$ & $\mathrm{L}_{\mathrm{c}, \text { peak }}$ & & \\
\hline \multicolumn{8}{|c|}{ Normal ammunition S\&B FMJ $8 \mathrm{~g}$} \\
\hline 1 & 121.8 & 146.1 & 122.6 & 146.6 & 153.6 & 342 & 469 \\
\hline 2 & 121.4 & 145.7 & 122.2 & 146.5 & 154.2 & 346 & 479 \\
\hline Mean & 121.6 & 145.9 & 122.4 & 146.6 & 153.9 & 344 & 474 \\
\hline \multicolumn{8}{|c|}{ Normal ammunition S\&B FMJ 8g + silencer A-Tec PMM-6 } \\
\hline 1 & 100.2 & 120.7 & 99.9 & 120.8 & 128.0 & 344 & 474 \\
\hline 2 & 101.7 & 123.6 & 101.3 & 123.8 & 131.7 & 346 & 480 \\
\hline Mean & 101.0 & 122.2 & 100.6 & 122.3 & 129.9 & 345 & 477 \\
\hline \multicolumn{8}{|c|}{ Subsonic ammunition S\&B FMJ Subsonic $9.7 \mathrm{~g}$} \\
\hline 1 & 112.9 & 137.4 & 114.1 & 138.5 & 141.6 & 274 & 363 \\
\hline 2 & 113.5 & 138.7 & 114.6 & 138.4 & 141.6 & 277 & 372 \\
\hline Mean & 113.2 & 138.1 & 114.4 & 138.5 & 141.6 & 275 & 368 \\
\hline \multicolumn{8}{|c|}{ Subsonic ammunition S\&B FMJ Subsonic 9.7g + silencer A-Tec PMM-6 } \\
\hline 1 & 101.3 & 124.0 & 100.7 & 122.7 & 132.8 & 278 & 374 \\
\hline 2 & 98.3 & 124.0 & 97.2 & 122.9 & 135.2 & 273 & 362 \\
\hline Mean & 99.8 & 124.0 & 99.0 & 122.8 & 134.0 & 276 & 368 \\
\hline
\end{tabular}

Source: own study 
The individual symbols mean:

- LAeq,1s - average A-sound level measured from $10 \mathrm{~ms}$ before the shot to 1 second, i.e. until the sound disappears completely,

- LAmax - the maximum A-sound level achieved at the time of the shot,

- LCeq,1s - average C sound level measured from $10 \mathrm{~ms}$ before the shot to 1 second, i.e. until the sound disappears completely,

- Lcmax - the maximum $\mathrm{C}$ sound level achieved at the time of the shot,

- Lcpeak - the maximum peak $\mathrm{C}$ sound level reached at the time of the shot.

The table also includes the results of measurements of the initial projectile velocity $V o$ and the initial energy Eo.

Analysing the obtained results, it can be concluded that the use of subsonic ammunition allows to reduce the A-sound level in relation to standard ammunition by an average of $8.4 \mathrm{~dB}$, while the peak level of $\mathrm{C}$-sound by about $12.3 \mathrm{~dB}$. Therefore, it is an effective method of noise reduction, whereby it should be remembered that reducing the initial velocity of the projectile Vo from approx. 345 to $276 \mathrm{~m} / \mathrm{s}$ also reduces the energy of the Eo projectile from approx. 474 to $368 \mathrm{~J}$. This obviously results in a different trajectory of the projectile and much more precipitation. The use of the A-Tec PMM- 6 acoustic silencer allowed to reduce the A-sound level in the case of standard ammunition by $20.6 \mathrm{~dB}$ and the peak $\mathrm{C}$-sound level by $24.0 \mathrm{~dB}$. It is about $4 \mathrm{~dB}$ less than stated by the manufacturer (in the case of shooting with a dry silencer), but it is still a satisfactory result. In the case of subsonic ammunition, the noise level $A$ was reduced by $13.4 \mathrm{dBA}$ and the peak $\mathrm{C}$ level by $7.6 \mathrm{~dB}$ after the use of a silencer. The much lower effectiveness is related to the noise emitted by the bolt movement and the noise coming from the inside of the barrel after opening the bolt (during reloading). The silencer only reduces the noise coming out of the barrel.

The effectiveness of the tested noise reduction measures as a function of octave frequencies is summarized in Fig. 5.
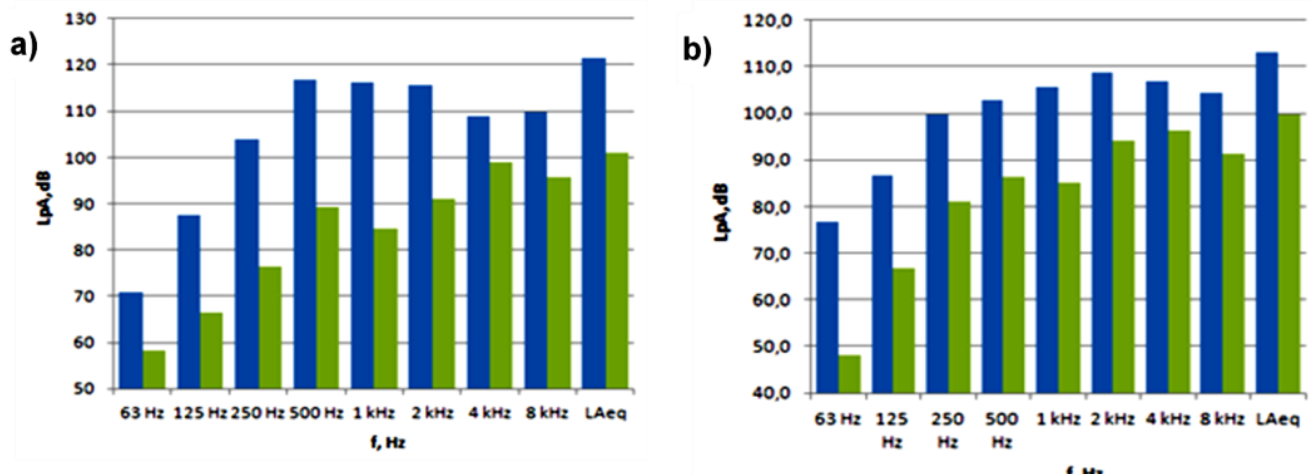

Fig. 5 Shot noise reduction during shooting without (blue) and with a silencer (green): a) normal ammunition, b) subsonic ammunition

The presented spectra clearly show that in the case of shooting with ordinary ammunition, the noise spectrum is dominated by low and medium frequencies. 
When subsonic ammunition is used, the share of these frequencies is lower and the shot becomes slightly quieter. On the other hand, the use of an acoustic silencer allows not only to significantly reduce the noise level, but also to change the structure of the sound to high-frequency, which is much more pleasant for the ear.

\section{EVALUATION OF THE REDUCTION OF THE SHOOTER'S EXPOSURE TO NOISE WITH SUBSONIC AMMUNITION AND SILENCER}

In order to illustrate the exposure of an exemplary sport shooter to noise during e.g. shooting training, it was decided to calculate the noise dose and the multiplicity $\mathrm{K}$ of the NDN value exceeded using the indirect method. It was assumed that the shooter fires 200 shots in eight hours from a Glock 45 pistol. Based on the measurements, the LEx level of one acoustic event was assumed to be equal to LAeq,1s because it was determined for the time of 1 second (Fig. 4). On this basis, the 8-hour exposure was calculated and other assessment parameters were determined. The calculations were made for the shooter firing without and with ear protectors when firing regular and subsonic ammunition and additionally with a noise silencer.

The results of the calculations performed in the case of shooting without hearing protectors are presented in Table 5, and with Peltor Optime I protectors in Table 6.

Table 5 Exposure to noise of a shooter not using hearing protectors

\begin{tabular}{|c|c|c|c|c|c|c|}
\hline \multirow{2}{*}{$\begin{array}{l}\text { Type of protection } \\
\text { against noise }\end{array}$} & \multicolumn{3}{|c|}{ Sound level in $\mathrm{dB}$} & \multicolumn{3}{|c|}{$\begin{array}{l}\text { Assessment of exposure } \\
\text { to noise }\end{array}$} \\
\hline & $\mathrm{L}_{\text {Aeq, } 1 \mathrm{~s}}$ & $L_{\text {Amax }}$ & $L_{\text {cpeak }}$ & $\begin{array}{l}L_{E X, 8 \mathrm{~h}} \\
{[\mathrm{~dB}]}\end{array}$ & $\begin{array}{c}\mathrm{E}_{\mathrm{A}, \mathrm{Te}} \\
{\left[\mathrm{Pa}^{2} \mathrm{~s}\right]}\end{array}$ & $\mathbf{K}$ \\
\hline $\begin{array}{l}\text { No protections - normal } \\
\text { ammunition S\&B FMJ 8g }\end{array}$ & 121.6 & 145.9 & 153.9 & 100.0 & 115434 & 31.71 \\
\hline $\begin{array}{l}\text { Normal ammunition + } \\
\text { acoustic silencer A-Tec } \\
\text { PMM-6 }\end{array}$ & 101.0 & 122.2 & 129.9 & 79.4 & 1005 & 0.28 \\
\hline $\begin{array}{l}\text { Subsonic ammunition } \\
\text { S\&B FMJ 9,7g }\end{array}$ & 113.2 & 138.1 & 141.6 & 91.6 & 16685 & 4.58 \\
\hline $\begin{array}{l}\text { Subsonic ammunition + } \\
\text { silencer A-Tec PMM-6 }\end{array}$ & 98.8 & 124.0 & 134.0 & 78.2 & 763 & 0.21 \\
\hline Acceptable values & - & 115 & 135 & 85 & 3640 & 1 \\
\hline
\end{tabular}

Source: own study

When performing the assessment of the shooter's noise exposure, the measured and calculated values of the noise parameters were compared with the permissible values defined in Journal of Laws of 2018, item 1286. In the tables, the values in excess of the permissible levels are marked in red, while the values lower than the permissible levels are marked in green. On the basis of the obtained results, it can be concluded that when firing shots without hearing protectors with the use of normal ammunition and subsonic ammunition, all 
noise parameters (LAmax, LCpeak, LEx,8h, EA,Te, K) exceed the permissible values, although in the case of using subsonic ammunition, the number of times exceeded $\mathrm{K}$ decreased from the value of 31.71 to the value of 4.58 . Nevertheless, the overrun still occurs. By using the A-Tec PMM- 6 acoustic silencer on the weapon, all parameters are reduced to the permissible values, except for the maximum value $L_{A m a x}$. The multiplicity of the $\mathrm{K}$ exceedance is reduced to 0.28 in the case of normal ammunition and a silencer and to $0.21 \mathrm{in}$ the case of subsonic ammunition in combination with a silencer. However, the problem is the impulse nature of the noise and the excess value LAmax. Therefore, additional hearing protectors should be used.

In order to check the effectiveness of the use of the hearing protectors, the Asound level present at the shooter's eardrum (i.e. under the protector) was estimated, assuming that he was wearing Peltor Optime I hearing protectors. The calculations were made using the HML method, which is based on the knowledge of the sound levels $\mathrm{C}$ and $\mathrm{A}$ of the noise at the stand and the knowledge of the $\mathrm{H}, \mathrm{M}$ and $\mathrm{L}$ attenuation value of the protector (Kotarbińska, 2004). In the case of Peltor Optime I protectors, the value of wideband attenuation is $S N R=27 \mathrm{~dB}$, attenuation in the high-frequency band $\mathrm{H}=32 \mathrm{~dB}$, in the medium-frequency band $M=25 \mathrm{~dB}$ and in the low-frequency band $\mathrm{L}=15$ $\mathrm{dB}$. The obtained calculation results are presented in Table 6 .

Table 6 Exposure to noise of a shooter equipped with Peltor Optime I hearing protectors

\begin{tabular}{|l|c|c|c|c|c|c|}
\hline \multirow{2}{*}{$\begin{array}{l}\text { Type of protection against } \\
\text { noise }\end{array}$} & \multicolumn{3}{|c|}{ Sound level in dB } & \multicolumn{3}{c|}{ Assessment of exposure } \\
\cline { 2 - 7 } & $\mathbf{L}_{\text {Aeq, 1s }}$ & $\mathbf{L}_{\text {Amax }}$ & $\mathbf{L}_{\text {Cpeak }}$ & $\begin{array}{c}\mathbf{L}_{\text {EX,8h }} \\
{[\mathbf{d B}]}\end{array}$ & $\begin{array}{c}\mathbf{E}_{\text {A,Te }} \\
{\left[\mathbf{P a}^{2} \mathbf{s}\right]}\end{array}$ & K \\
\hline $\begin{array}{l}\text { No protections - normal } \\
\text { ammunition S\&B FMJ 8g }\end{array}$ & 94.5 & $-*$ & 133.9 & 72.9 & 225 & 0.06 \\
\hline $\begin{array}{l}\text { Normal ammunition + } \\
\text { acoustic silencer A-Tec } \\
\text { PMM-6 }\end{array}$ & 71.8 & $-*$ & 97.9 & 50.2 & 1.21 & 0.0003 \\
\hline $\begin{array}{l}\text { Subsonic ammunition S\&B } \\
\text { FMJ 9,7g }\end{array}$ & 86.8 & $--^{*}$ & 121.6 & 65.2 & 38.2 & 0.0105 \\
\hline $\begin{array}{l}\text { Subsonic ammunition + } \\
\text { silencer A-Tec PMM-6 }\end{array}$ & 69.9 & $-*$ & 102.0 & 48.3 & 0.78 & 0.0002 \\
\hline Acceptable values & - & 115 & 135 & 85 & 3640 & 1 \\
\hline
\end{tabular}

Source: own study

*) no methodologies for estimating the LAmax value under the protector

Based on the obtained results, it can be concluded that the use of Peltor Optime I hearing protectors allows to significantly reduce the shooter's exposure to noise. All assessment parameters are below the limit values and the risk from exposure to impulse noise in the shooter is low. It follows that when using hearing protectors, the use of additional protection (such as subsonic ammunition or silencers) is not necessary. However, it should be noted that there are currently no methodologies allowing for the estimation of the LAmax sound level under the hearing protector, so the value of this parameter was not 
addressed. Therefore, the combination of at least two methods of protection against noise, e.g. earmuffs and subsonic ammunition or earmuffs and acoustic silencer, will provide shooters with maximum hearing protection.

\section{SUMMARY}

The article presents the problem of exposure of sports shooters to excessive noise. Various possibilities of noise reduction during shooting, e.g. during training, are discussed and the use of noise reducing solutions such as subsonic ammunition and silencers is analysed in detail. The conducted experimental studies clearly showed the high effectiveness of the above solutions. The use of subsonic ammunition in the case of shooting with the Glock 45 pistol allowed to reduce the noise at the shooter's ear by more than $8 \mathrm{~dB}(A)$, while the use of the A-Tec PMM-6 silencer resulted in a noise reduction of more than $20 \mathrm{~dB}(\mathrm{~A})$. The combination of these two solutions does not give much greater noise reduction. In total, a reduction of more than $21 \mathrm{~dB}(\mathrm{~A})$ was achieved. The gunshot noise emitted from the barrel is effectively reduced by the silencer, but the noise associated with the backward movement of the bolt, the escape of some gases through the exposed cartridge chamber during automatic reloading and the aerodynamic noise associated with the flight of the bullet remain.

In conclusion, it should be clearly stated that the use of the above noise reduction measures allows to significantly reduce the noise emitted during shots and thus significantly reduce the risk of hearing damage in shooters. It is worth noting that despite the use of silencers and subsonic ammunition, hearing protectors must be worn at the same time. The tests carried out clearly showed that it is possible to significantly reduce the acoustic energy accompanying the bang of a firearm by applying the measures described above. This issue should also be considered in a slightly broader aspect. The use of noise silencers on the weapon during shooting allows not only to protect the hearing of the shooter, but also allows to reduce the noise reaching other users of the shooting range. In addition, noise emission from the shooting range area towards residential buildings usually located nearby is reduced. Therefore, the use of acoustic silencers should be approved for use in shooting ranges and in hunting as soon as possible, and even required, as is the case in Scandinavian countries. By reducing excessive and disturbing noise, we protect ourselves and the environment.

\section{REFERENCES}

Boczkowski, A. (2020). Acoustic modelling of sport and hunting shooting ranges in the aspect of shaping noise emissions into the environment. Monograph. Multidisciplinary Aspects of Production Engineering. Warszawa, Sciendo, pp. 308-319.

Młyński, R. (2013). Hałas impulsowy. Stosowanie ochronników słuchu. Centralny Instytut Ochrony Pracy, Państwowy Instytut Badawczy, Warszawa. 
Konopka, W., Pawlaczyk-Łuszczyńska, M., Zalewski, P., Miłoński, J. (2002) Ocena i analiza środowiska akustycznego u żołnierzy narażonych na hałas impulsowy. Medycyna Pracy, pp. 391-396.

Pawlaczyk-Łuszczyńska, M. (2010). Minimalizowanie ryzyka uszkodzenia słuchu w miejscu pracy poradnik dla pracowników BHP, PIS, PIP, pracodawców i pracowników. Oficyna Wydawnicza Instytutu Medycyny Pracy im. prof. J. Nofera. Łódź.

Dz.U.2018, poz. 1286, (2018). Rozporządzenie Ministra Rodziny, Pracy i Polityki Społecznej z dnia 12 czerwca 2018 r. w sprawie najwyższych dopuszczalnych stężeń i natężeń czynników szkodliwych dla zdrowia w środowisku pracy.

Kotarbińska, E. (2004). Ochronniki słuchu - przepisy, rozwiązania konstrukcyjne, metody doboru. Centralny Instytut Ochrony Pracy. PIB. Warszawa.

Kozłowski, E. (2012). Środki ochrony narządu słuchu. Państwowa Inspekcja Pracy Główny Inspektorat Pracy. Warszawa.

Rusiecki, M. (2013). Tłumiki do broni palnej. PUW Roksana. Warszawa.

Abstract: The intensive development of sport shooting and the significant increase in the number of people using sport and recreational shooting ranges also increases the risk of hearing damage to shooters, due to exposure to impulse noise from the shots of firearms. This article discusses the methodology for assessing shooters' exposure to noise and identifies and extensively discusses possible ways to minimise this exposure. It then describes a research experiment carried out to measure and calculate the effectiveness of noise reduction by means of acoustic silencers when shooting with typical weapons in the most popular sporting and hunting calibres. The experiment also included firing tests with subsonic ammunition. On this basis, conclusions were drawn regarding the possibility of reducing impulse noise during shooting and the possibility of eliminating the risk of hearing damage.

Keywords: noise, shooting range, acoustic silencers, exposure to noise, noise risk assessment 